\title{
Will the Discussion on Digital Sequence Information on Genetic Resources Contribute to the "Evolution" of CBD?
}

Kunihiko Kobayashi ${ }^{\ddagger}$

‡ Research Institute for Humanity and Nature, Kyoto city, Japan

Corresponding author: Kunihiko Kobayashi (kkobayashi@chikyu.ac.jp)

Received: 29 May 2019 | Published: 13 Jun 2019

Citation: Kobayashi K (2019) Will the Discussion on Digital Sequence Information on Genetic Resources Contribute to the "Evolution" of CBD? Biodiversity Information Science and Standards 3: e36593.

https://doi.org/10.3897/biss.3.36593

\section{Abstract}

The discussion on digital sequence information (DSI) on genetic resources under the Convention on Biological Diversity (CBD) started from $13^{\text {th }}$ Conference of the Party (COP) held in Mexico 2016. The controversial negotiations on DSI continues, and the CBD Parties agreed on the $14^{\text {th }}$ COP with decision $14 / 20$ to seek further view and submissions on DSI. The issues at the CBD-COP are, according to Kobayashi (2018), the following:

1. terminology or definition of DSI;

2. the potential coverage of DSI under the CBD to ensure benefit sharing;

3. relationship between use of DSI and mutually agreed terms;

4. influence on the objectives of CBD;

5. traceability and;

6. relationship between utilization of DSI and public databases.

Among these issues, the first is pointed out by Australia as an issue leading to the amendment of the CBD. Also, the third is the issue regarding the rights and obligations of natural and legal persons. Halewood et al. (2018) proposed different views as a policy option, which are renegotiation of the legally binding instrument and adoption of a decision on mutually agreed terms in the current framework. Sollberger (2018) also pointed out that 
the most obvious solution could be to govern the use of sequence information via permission from national authority and contract between provider and user at the time of access to the original genetic resource.

On the other hand, the evolution of the international environment agreement is to embody the Convention and the Protocol through decisions or resolutions adopted by COP, in addition to the amendment of the Convention and the adoption of the Protocol. Tamura (1999) reviewed the role of COP under the international environment agreement as follows: adjusts interests among the Parties; implements the obligations under the agreement; and enables a consensus building framework for the development and implementation of the agreement. However, the decisions adopted by the COP are not legally binding, despite the lack of articles on this matter in the agreement, there are cases, for instance, that the decision of COP is to proceed with rule making and begin to be implemented in each Party (Recio 2018). Thus, this paper examines whether the issue on DSI in the CBD contributes to the evolution of the Convention or not through the discussion from COP13 to COP14, including the submission of the views from Party and stakeholders, an Ad Hoc Technical Expert Group (AHTEG) on DSI on genetic resources and decisionmaking.

As a tentative conclusion, the discussion on DSI could contribute to the evolution of the Convention. In confirming decision IV/20 of CBD-COP, COP decided to continue discussions on definition and scope, furthermore it is noted that mutually agreed terms can cover the benefits arising from the use of DSI on accessed genetic resources. This decision does not go beyond the current framework, but there is a possibility to create opportunities for the evolution or growth of the Convention, such as the development of standard contract models. The logic of this decision is the same as the derivatives of genetic resources identified during the negotiation of the Nagoya Protocol.

\section{Keywords}

digital sequence information, genetic resource, Convention on Biological Diversity

\section{Presenting author}

Kunihiko Kobayashi

\section{Presented at}

Biodiversity_Next 2019 


\section{Conflicts of interest}

There are no conflicts of interest to be disclosed in relation to this paper.

\section{References}

- Halewood M, Chiurugwi T, Hamilton RS, Kurtz B, Marden E, Welch E, Michiels F, Mozafari J, Sabran M, Patron N, Kersey P, Bastow R, Dorius S, Dias S, McCouch S, Powell W (2018) Plant genetic resources for food and agriculture: opportunities and challenges emerging from the science and information technology revolution. New Phytologist 217 (4): 1407-1419. https://doi.org/10.1111/nph.14993

- Kobayashi K (2018) Analysis of the views on "Digital Sequence Information on Genetic Resource" and its legal perspective. Papers on Environmental Information Science Volume 32: 303-308. [In Japanese]. https://doi.org/10.11492/ceispapers.ceis32.0_303

- $\quad$ Recio ME (2018) Transnational REDD+Rule Making: The Regulatory Landscape for REDD + Implementation in Latin America. Transnational Environmental Law 7 (2): 277-299. [In English]. https://doi.org/10.1017/S2047102518000122

- Sollberger K (2018) Digital sequence information and the Nagoya Protocol. Legal expert brief on behalf of the Swiss Federal Office for the Environment (FOEN), Australia

- Tamura M (1999) 国連気候変動枠組条約制度の発展と締約国会議決定 (initial translation; Evolution of the UNFCCC and the decision of the COP). 世界法年報 (Yearbook of World Law) 19: 23-46. [In Japanese]. https://doi.org/10.11388/ yearbookofworldlaw1986.2000.23 